\title{
The renal subcapsular site offers better growth conditions for transplanted mouse pancreatic islet cells than the liver or spleen
}

\author{
A. Mellgren, A. H.Schnell Landström, B. Petersson and A. Andersson \\ Department of Medical Cell Biology, Uppsala University, Uppsala, Sweden
}

Summary. In order to investigate the importance of the transplantation site for the replication of grafted islet cells, we implanted syngeneic mouse pancreatic islets intrasplenically, intraportally and subcapsularly in the kidney. Fourteen days later the alloxan-diabetic mice were killed after an injection of tritiated thymidine, and the graft-bearing organs fixed and processed for autoradiography. The highest labelling indices were recorded for subcapsularly grafted islets, followed by intraportal and intrasplenic islets in that order. In separate experiments some islet-containing kidney sections were immune stained for insulin before the autoradiographic process.
The labelling index of the insulin-positive cells was as high as in the entire islet cell population of the sections from the same mice stained with haematoxylin only. This indicates that the B cells of the islets replicate as often as the other islet cell types. The present data also suggest that the renal subcapsular space offers better growth conditions for transplanted islet cells than the liver or spleen.

Key words: Mouse pancreatic islets, islet transplantation, implantation sites, autoradiography, labelling index, islet cell replication.
Despite some promising new approaches to the isolation of islets of Langerhans from the adult human pancreas [1], this problem is still far from solved. An alternative procedure for preparing insulin-producing human cells intended for transplantation to diabetic patients is that of utilizing fetal material. Thus, in animal experiments one fetal rat pancreas was found to cure one diabetic adult recipient within 45 days provided insulin treatment was given [2]. No doubt the success of these experiments was due to a considerable growth of the graft.

It was the aim of the present study to evaluate to what extent the growth of grafted islet cells depends on the implantation site. Therefore, syngeneic mouse pancreatic islets were transplanted into three commonly used sites, namely the liver, the spleen and beneath the kidney capsule. At the end of a two-week observation period ${ }^{3} \mathrm{H}$-thymidine was injected and the graft-bearing organs processed for autoradiography. The replicatory activity of the transplanted islet cells was then determined by estimating their labelling indices (LI).

\section{Materials and methods}

\section{Animals}

Male and female inbred C57BL/6 mice, aged 3 to 5 months, belonging to a strain originally obtained from the Jackson Laboratory, Bar Harbor, Me, USA were used as islet donors. Three to 5 month old, syngeneic males of this strain, injected intravenously with alloxan ( $75 \mathrm{mg} / \mathrm{kg}$ body wt.; Sigma Chemicals, St. Louis, Mo, USA), served as islet recipients. Only mice with serum glucose concentrations $>$ $25 \mathrm{mmol} / 1$ were used. During the experimental period, the mice were allowed free access to tap water and laboratory chow.

\section{Islet isolation and implantation}

Pancreatic islets were prepared by a collagenase (Boehringer Mannheim, Mannheim, FRG) digestion method [3] from mice fasted overnight. Groups of approximately 100 islets were cultured free-floating for 1-2 days as described previously [4] in RPMI 1640 medium (Flow Laboratories, Irvine, UK) supplemented with $10 \%$ (vol/vol) calf serum (Statens Bakteriologiska Laboratorium, Stockholm, Sweden). Three routes for islet implantation were used. For intrasplenic and intraportal islet implantation groups of approximately 150 cultured islets were suspended in Hanks' balanced salt solution and injected, by means of a microinfusion set, either directly into the splenic pulp or via the portal vein, into anaesthetized (ether) alloxan-diabetic recipients. Likewise, the same number of islets were implanted by means of a braking pipette beneath the kidney capsule after a small incision had been made in the capsule. With this number of islets implanted at each site it was possible to recover them for the histological and autoradiographical process. Four different recipient groups are designated: (A) Mice implanted intraspenically and subcapsularly; (B) Mice implanted intrasplenically and intraportally; (C) Mice implanted intraportally and subcapsularly; (D) Mice implanted with islets at all three sites. Thus, mice in groups $\mathrm{A}, \mathrm{B}$ and $\mathrm{C}$ received approximately 300 islets and mice in group D received 450 islets. Blood samples for glucose determination were collected by retroorbital puncture before islet implantation and at death 2 weeks later. Serum glucose concentrations were determined with a glucose oxidase method using an automated analyser (Beckman Instruments, Fullerton, Calif., USA). Each mouse was injected intraperitoneally with $1 \mu \mathrm{Ci}{ }^{3} \mathrm{H}$-thymidine 
Table 1. Serum glucose and islet cell labelling indices (LI) of mice with islets implanted at two different sites

\begin{tabular}{|c|c|c|c|c|}
\hline Treatment & $\begin{array}{l}\text { Serum } \\
\text { glucose } \\
\text { before } \\
(\mathrm{mmol} / \mathrm{l})\end{array}$ & $\begin{array}{l}\text { Serum } \\
\text { glucose } \\
\text { after } \\
(\mathrm{mmol} / \mathrm{l})\end{array}$ & $\begin{array}{l}\text { Islet cell } \\
\text { LI }(\%)\end{array}$ & $\begin{array}{l}\text { LI ratios of } \\
\text { individual } \\
\text { mice }\end{array}$ \\
\hline $\begin{array}{l}\text { Islet implantation } \\
\text { intrasplenically and } \\
\text { beneath the kidney } \\
\text { capsule } \\
(n=9)\end{array}$ & $31.9 \pm 1.4$ & $10.6 \pm 1.2^{\mathrm{a}}$ & $\begin{array}{l}0.52 \pm 0.14 \\
\text { (spleen islets) } \\
1.22 \pm 0.30^{c} \\
\text { (kidney } \\
\text { islets) }\end{array}$ & $2.97 \pm 0.45$ \\
\hline $\begin{array}{l}\text { Islet implantation } \\
\text { intrasplenically and } \\
\text { intraportally } \\
(n=6)\end{array}$ & $33.4 \pm 1.0$ & $16.8 \pm 3.2^{\mathrm{a}}$ & $\begin{array}{l}0.56 \pm 0.17 \\
\text { (spleen islets) } \\
1.04 \pm 0.27^{\mathrm{b}} \\
\text { (liver islets) }\end{array}$ & $2.48 \pm 0.53$ \\
\hline $\begin{array}{l}\text { Islet implantation } \\
\text { intraportally and } \\
\text { beneath the kidney } \\
\text { capsule } \\
(n=10)\end{array}$ & $41.6 \pm 3.1$ & $15.1 \pm 2.9^{\mathrm{a}}$ & $\begin{array}{l}0.91 \pm 0.21 \\
\text { (liver islets) } \\
1.76 \pm 0.33^{\mathrm{c}} \\
\text { (kidney } \\
\text { islets) }\end{array}$ & $2.18 \pm 0.20$ \\
\hline
\end{tabular}

Serum glucose values before and after the islet implantation. Islet cell labelling indices were estimated after scoring at least 1500 (spleen and kidney) or 1000 (liver) islet cell nuclei in each animal. The ratio between the islet cell LI of the two differently located grafts was calculated in each mouse. Values are expressed as mean \pm SEM. ${ }^{a}$ denotes $p<0.001$ when tested against corresponding serum glucose values before islet implantation. ${ }^{\mathrm{b}}$ denotes $p<0.05$ and ${ }^{\mathrm{c}} p<0.01$ when $L I$ values were tested between the two actual different implantation sites using a paired Student's t-test

(Amersham International, Amersham, UK) per gram body wt 60 min before killing. The islet graft-bearing organs were then rapidly removed and the entire spleen fixed in Bouin's solution. Islet-containing parts of the livers and kidneys could most often be identified as whitish spots; these sections were dissected free and subsequently fixed.

\section{Autoradiography}

The fixed specimens were embedded in paraffin and sectioned at $7 \mu \mathrm{m}$. Every third slide was stained with haematoxylin-eosin. These slides were used for identification of islet-containing areas of the different tissues. Consecutive slides were taken for autoradiography as described previously in detail [5]. To determine the islet cell LI, radioactively labelled nuclei were counted at a magnification of $\times 1000$ and expressed as a percentage of the total number of nuclei scored. The shape of the cell nuclei and the amount of cytoplasm of the grafted islet cells were used for judging their identity. Apparent non-endocrine cells with sparse cytoplasm and elongated nuclei containing condensed chromatin were not scored. In each animal a minimum of 1500 (intrasplenic and subcapsular sites) or 1000 islet cell nuclei (intraportal) were counted. In order to constitute a labelled cell at least 10 grains were required over the nucleus. A great majority of the labelled cells had more than 20 grains over their nuclei. The background count was 1 or 2 grains per nucleus or less. In the series of consecutive islet containing sections only every third was used for determinations of the LI.

In order to verify the replicating activity of the transplanted islet cells some islet containing kidney sections were stained according to the PAP technique [6] for the identification of insulin positive cells. An anti-bovine insulin serum raised in guinea pigs (Bio-Yeda, Rehovot, Israel) was used as the primary serum. The second antibody and the PAP complex were from Dakopatts, Glostrup, Denmark. The whole staining procedure was carried out before the autoradiographic processing. These sections were only counterstained with haematoxylin. A minimum of 2000 insulin-positive cells were scored and the number of radioactively labelled nuclei estimated as described above.

\section{Statistical analysis}

Data are expressed as mean \pm SEM. Differences were tested with the Student's t-test for paired data.

\section{Results}

In all groups of islet-implantated mice the hyperglycaemia was nearly normalized during the two-week observation period (Table 1). The islet cell LI of the spleen islets was lower than that of the subcapsular and intraportal islets. When calculating a ratio for the LI of the intrasplenic islets and the intraportal or subcapsular islets in each individual mouse, it was found that the LI of the intrasplenic islets was almost only one-third of that in the intraportal or subcapsular islets. In the third group of mice the subcapsular islets had a LI twice as high as the intraportal.

In a separate group of alloxan-diabetic mice, islets were implanted at all three implantation sites. Of six operated mice three died within 2 days after the operation and one was unsuitable for autoradiography. In the two successfully treated mice serum glucose values decreased from of 31.3 and $37.3 \mathrm{mmol} / 1$ to 9.6 and $9.2 \mathrm{mmol} / 1$ respectively. In the first mouse the islet cell $L I$ values of the subcapsular, intraportal and intrasplenic islets were $3.16,2.31$ and $1.10 \%$ and the corresponding values for the second mouse $1.41,0.98$ and $0.94 \%$.

In order to evaluate the identity of the labelled islet cells consecutive sections of seven autoradiographically processed kidney sections from separate animals were immune stained for insulin before being processed for autoradiography. The islet cell LI of the conventionally treated sections was found to be $2.33 \pm 0.37 \%(n=7)$ and the corresponding value for the insulin-positive cells of the immune stained sections $2.40 \pm 0.56 \%$ $(n=7)$.

\section{Discussion}

The present data support and extend our previous knowledge of the replicatory capacity of grafted islet cells as evaluated either by means of morphometric [7] or autoradiographic techniques [5]. We chose an experimental protocol to implant relatively few islets in diabetic mouse recipients, since there is obviously a stimulation of DNA synthesis if a hyperfunctional state of the $\mathrm{B}$ cells is maintained [5]. This study also demonstrates that the B cells replicate actively, since as great a proportion of the insulin-positive cells as of the islet cells in conventionally stained sections was radioactively labelled. We did not perform a differential cell count of the different islet cell types in the immunostained grafts, but we estimate from the overall light microscopic appearance of the islet grafts that they were composed of about $80-90 \%$ B cells. It was noteworthy that not less than $1-2 \%$ of the adult mouse islet cells synthesized 
DNA when grafted, which is three to four times more than in the islets located in the pancreas [5]. Most probably even higher replicatory rates should have been recorded with fetal mouse islet grafts, but there is no technique presently available for large-scale production of such islets. Indeed, human fetal islet-like structures, grafted into the renal subcapsular site in normoglycaemic nude mice, had labelling indices of about $8 \%$ under otherwise similar experimental conditions, as in the present study, but the identity of the replicating cells in that study was not checked in detail [8].

It is obvious from the present data that, of the implantation sites tested in this study, the renal subcapsular site offers the best conditions for proliferation of the grafted islet cells. Differences in blood flow and hence availability of tritiated thymidine between the sites cannot explain these observations. Such a difference would only show up as varying numbers of grains covering the DNA-synthesizing islet cells. Although these sites are those most frequently used for islet implantation, several other sites can also be successfully used for this purpose. It is, however, unlikely that, for instance, the subcutaneous and intramuscular sites with less efficient blood supply should be more convenient than any of those presently used. It is not easy to ascribe the reason for the superiority of the subcapsular space. It is noteworthy from a morphological point of view that in the renal subcapsular site all islets tend to merge into a single, large cluster of cells, whereas islets transplanted into the spleen and liver are more dispersed. It is also possible that the renal islets have a better supply of well-oxygenized blood than islets in the other two sites, perhaps due to differences in the rates of neovascularization. Indeed, our finding of numerous mast cells in and beneath the kidney capsule close to the islet grafts may be taken to indicate an active angiogenesis in this area $[9,10]$.

Acknowledgements We thank Ms. A.-B.Andersson, C.Bittkowski, A. Nordin and E. Törnelius for skilled technical assistance and Ms. A.Snellman for typing the manuscript. Financial support was received from the Swedish Medical Research Council (12X-109, 12X2297, 17X-07501), the Swedish Diabetes Association, the Nordic Insulin Fund and the juvenile Diabetes Foundation International.

\section{References}

1. Gray DWR, McShane R, Grant A, Morris PJ (1984) A method for isolation of islets of Langerhans from the human pancreas. Diabetes 33: 1055-1061

2. Brown J, Heininger D, Kuret J, Mullen Y (1981) Islet cells grow after transplantation of fetal pancreas and control of diabetes. Diabetes 30:9-13

3. Howell SL, Taylor KW (1968) Potassium ions and the secretion of insulin by islets of Langerhans incubated in vitro. Biochem $\mathrm{J} 108$ : $17-24$

4. Andersson A (1978) Isolated mouse pancreatic islets in culture: Effects of serum and different culture media on the insulin production of the islets. Diabetologia 14: 397-404

5. Swenne I, Andersson A (1984) Effect of genetic background on the capacity for islet cell replication in mice. Diabetologia 27 : 464-467

6. Steinberger L, Hardy PH, Cuclins JJ, Meyer HG (1970) The labelled antibody enzyme method of immunohistochemistry. Preparations and properties of soluable antigen-antibody complex (horseradish peroxidase-antihorseradish peroxidase) and its use in identification of spirochetes. J Histochem Cytochem 18: 315-333

7. Andersson A, Eriksson U, Petersson B, Reibring L, Swenne I (1981) Failure of successful intrasplenic transplantation of islets from lean mice to cure obese-hyperglycaemic mice, despite islet growth. Diabetologia 20: 237-241

8. Sandler S, Andersson A, Schnell A, Mellgren A, Tollemar J, Borg H, Petersson B, Groth C-G, Hellerström C (1985) Tissue culture of human fetal pancreas. Development and function of Bcells in vitro and transplantation of explants to nude mice. Diabetes 34: 1113-1119

9. Schnell Landström AH, Andersson A, Nordin A, Pettersson H, Borg LAH (1986) Lysosomal changes associated with decreased crinophagy in B cells of pancreatic islets transplanted into diabetic recipients. Abstract accepted for presentation at the 22nd EASD Meeting, Rome

10. Folkman J (1985) Toward an understanding of angiogenesis: Search and discovery. Perspectives in Biology and Medicine 29: $1-36$.

Received: 23 June 1986

and in revised form: 2 July 1986

Dr. Arne Andersson

Department of Medical Cell Biology

BMC

P.O. Box 571

S-75123 Uppsala

Sweden 